\title{
Physical and nutritional quality of retails cakes of Dhaka city
}

\author{
F. Begum ${ }^{1 *}$, A. K. Sarker ${ }^{2}$, S. Ahmed ${ }^{1}$, K. Mondal ${ }^{1}$ and S. Anjum ${ }^{1}$ \\ ${ }^{1}$ Applied Nutrition Section, IFST, BCSIR, Dhaka-1205, Bangladesh \\ ${ }^{2}$ Plant Protein Research Section, IFST, BCSIR, Dhaka-1205, Bangladesh
}

\begin{abstract}
The nutrient content and other quality parameters of retails cake samples collected from different markets of Dhaka city was evaluated. Irrespective of the brand or types of cake analyzed, none of the 13 retails cakes samples were found comply with BSTI standard weight and on an average, 5-10g less-weight was observed compared to the labeled weight. The moisture content was found within the BSTI acceptable level. The protein content (crude) ranging from $4.3 \%$ to $6.5 \%$ was observed, indicating that the cakes were prepared using flour containing low protein that gives softness to the cakes. On the other hand, negligible amount of fiber contents $(0.007-0.244 \%)$ was observed indicated that no effect on protein digestibility by pepsin and also absorption of fats. However, acid values (AV) of five cake samples were within the acceptable range $(0.69-1.00 \mathrm{mg} \mathrm{KOH} / 100 \mathrm{~g})$ of BSTI standard and the remaining eight samples were found higher (1.07-4.75 $\mathrm{mg} \mathrm{KOH} / 100 \mathrm{~g})$ than the acceptable limit. The peroxide values were found higher $(20.27-49.4 \mathrm{mEq} / \mathrm{kg})$ in all thirteen cake samples analyzed, indicated that all fats were in rancid condition. The iodine values (62.18-120.22) of extracted fats were low which indicates saturated nature of fats. The acid insoluble ashes of eight cake samples were higher than the permissible limit (0.1\%) compared to BSTI standard. Metal content (sodium, calcium) and trace metal (iron) contents was found in the range of $24.43-149.15 \mathrm{mg} / 100 \mathrm{~g} ; 32.59-69.70 \mathrm{mg} / 100 \mathrm{~g}$ and $0.96-8.18 \mathrm{mg} / 100 \mathrm{~g}$, respectively, which is higher than the BSTI standard. Therefore, the retails cake samples analyzed was of both good and poor quality.
\end{abstract}

Keywords: Cakes; Proximate analysis; Saturated Fat; Rancidity; Solubility; Minerals

\section{Introduction}

Cake is a form of food, typically a sweet, baked dessert (Anuradha et al., 2010). Cakes normally contain a combination of flour, sugar, eggs, and butter or oil, with some varieties also requiring liquid (typically milk or water) and leavening agents (such as yeast or baking powder). Flavorful ingredients like fruit purées, nuts or extracts are often added, and numerous substitutions for the primary ingredients are possible (Cauvain et al., 2006). In Bangladesh, cakes are normally eaten as a dessert of choice at ceremonial occasions such as weddings, anniversaries and birthdays. Cake produced from wheat flour alone lack adequate protein needed for growth, repair of tissues and building of cells (Tull et al., 2000). The flour properties depend on the experience of flour producer, wheat varieties and composition of wheat (Edmund et al., 2008). Al- Dmoor et al. (2012) studied the properties of ten cakes flour which often produced from one or mix of imported hard wheat. As much as the demand for pastry products increase, the cost of the products also becomes very expensive (Dotsey et al., 2009). Knowledge of the nutrient content of foods is essential for many types of nutrition research and applied nutrition projects, including the interpretation of food consumption studies, the nutritional assessment of food supplies and the planning of nutrition ally adequate diets. Appropriate nutrient data bases are not always readily available for these activities. Bangladesh standard and testing institute (BSTI) has set up a specification for cake that will help to maintain the good quality of cake (BDS, 2006). Many scientific studies have included the measurement of nutrients in foods (Rita et al., 2010) and reports of these nutrient values are found throughout the scientific literature (Malik et al., 1976; Rahaman et al., 1999).

This study thus, seeks to evaluate the nutrients composition as well as the acceptability of cakes produced by various local cake industries from wheat flour, sugar, eggs, and butter or oil with the aim of promoting utilization in the city people.

\section{Materials and methods}

Sample collection

Adequate number of branded or non-branded cake samples were purchased from the local market of Dhaka city and

\footnotetext{
*Corresponding author. e-mail: ferdousi.ifst@gmail.com, salmaifst@yahoo.com
} 
brought to the laboratory within 2 hours of purchase and analyzed.

\section{Methods of analysis}

The nutrition content including moisture, carbohydrate, protein, fat and minerals were determined using the standard AOAC, 1975 method. All the reagents including hydrochloric acid, acetic acid, and phosphoric acid used in this study were analytical grade and 1, 10 phenanthroline, ammonium acetate, potassium iodide, bromine and sodium hydroxide were BDH brand and purchased from local market. Stock solutions were prepared using sterile distilled water and kept at $4^{\circ} \mathrm{C}$.

\section{Moisture content (MC)}

The freshly ground samples (about $10 \mathrm{~g}$ ) were allowed to dry at $105^{\circ} \mathrm{C}$ in an oven until constant weight was obtained (AOAC, 1975). The moisture content (g/100g) was determined as [100X (Dry Matter, DM/ sample weight)], where DM was the residue remaining after drying. The dried samples were kept for analysis of ash.

Ash

Ash content was determined as the residue left after ashing the sample $(5-7 \mathrm{~g})$ at $300^{\circ} \mathrm{C}$ for $1 \mathrm{~h}$ followed by another $4 \mathrm{~h}$ at $550 \pm 10^{\circ} \mathrm{C}$ in a muffle furnace (AOAC, 1975).

Fat

Fat was determined by the Soxhlet extraction procedure (AOAC, 1975) using $10 \mathrm{~g}$ of samples and petroleum spirit. Extraction was done continuously for $8 \mathrm{hrs}$. The fat quality factors such as acid value, iodine value, peroxide value and saponification value were determined following the standard (AOAC, 1975) method.

\section{Crude fibre (CF)}

CF (g/100g) was determined using an automated fibre determination system (AOAC, 1975). For samples having a fat content of greater than $10 \%$, defatted ones were used so as not to interfere with $\mathrm{CF}$ determination.

\section{Crude protein $(\mathrm{CP})$}

CP (g/100g) was determined by the Micro-Kjeldahl technique, using an automated nitrogen determination system (AACC, 2000). The protein factor used was 6.25. The quality of the protein was determined by estimating the solubili- ty of the protein in water, salt solution, alkali and alcohol (Salma et al.).

\section{Carbohydrate (CHO)}

As proximate analysis was carried out, $\mathrm{CHO}(\mathrm{g} / 100 \mathrm{~g})$ also referred to as Nitrogen Free Extract was obtained by the following calculation $[\mathrm{CHO}=100-($ Moisture + Ash + Fat + $\mathrm{CP})]$ on a dry matter basis.

\section{Energy content (EC).}

Energy was determined using an adiabatic bomb calorimeter (Parr Instrument). Cake samples were made into pellets on a briquette press $(12.5 \mathrm{~mm}$ in diameter) prior to bombing at a pressure of 25atm (Anon, 1970).

\section{Minerals}

The minerals content such as sodium, potassium, and calcium were determined by 10 AL flame photometer (Tokyo Photoelectric Co. Ltd., Japan) and iron content was estimated by UV-spectrophotometric method using OPTIMA UVVis spectrophotometer (Model SP 3000).

\section{Statistical analysis}

Data were subjected to Analysis of Variance (ANOVA) using Statistical software SPSS for Window version 16.0. When ANOVA showed a significant effect at a level of 5\%, treatment means were compared using Duncan Multiple Range Test (DMRT) of Post Hoc was performed.

\section{Results and discussion}

Thirteen retail cake samples (Plain and Fruit) were collected from local market. The physical characteristics including shape, size and weight of cake samples were shown in Table I. The shape of all the cake analyzed was found rectangular, a popular shape liked by the consumers in Bangladesh. The size of the cakes analyzed varied $\left(453.84 \mathrm{~cm}^{3}\right.$ to 530.0 $\mathrm{cm}^{3}$ ) depending on the variation of weight. The actual weight of the cake was less than that of labeled weight, claimed by the manufacturers. The main reason is the evaporation of water molecules during distribution and storage and consequently leads to lower weight. Although the size and weight of the cakes had no relations with the nutrient content expressed in percentage of the weight of the cake, but had a relationship with the consumer acceptability and consumption of the amount of cakes.

The results of the nutrition content including moisture, carbohydrate, protein, fat are presented in Table II. The mois- 
ture content of the samples varied from $18.60-22.76 \%$ indicating that the products entrapped moisture from atmosphere due to the lack of proper packaging after baking. Even though the results comply with the BSTI moisture content value, but higher moisture content could shorten the shelf life of the cake samples. denaturation of protein and thereby decreasing the protein content in cakes analyzed. There can be interaction of pro tein with carbohydrates or lipid oxidation products which may result in nutritional unavailability of protein (Manay et al., 1987). It has been reported that roasting, baking, and frying could adversely affect the nutritive value of food pro-

Table I. Physical characteristics of the cakes

\begin{tabular}{llllccc}
\hline $\begin{array}{c}\text { Sl. } \\
\text { No. }\end{array}$ & $\begin{array}{c}\text { Trade name of the } \\
\text { cakes }\end{array}$ & $\begin{array}{c}\text { Type of the } \\
\text { cakes }\end{array}$ & $\begin{array}{c}\text { Shape of the } \\
\text { cakes }\end{array}$ & $\begin{array}{c}\text { Volume of the } \\
\text { cakes }\left(\mathrm{cm}^{3}\right)\end{array}$ & $\begin{array}{c}\text { Actual weight of } \\
\text { the cakes }(\mathrm{g})\end{array}$ & $\begin{array}{c}\text { Weight of the cakes noted } \\
\text { on the label }(\mathrm{g})\end{array}$ \\
\hline 1 & L-V-N Plain Cake & Plain Cake & Rectangular & 522.60 & 492.70 & 500.00 \\
2 & Ro. Butter Cake & Plain Cake & Rectangular & 530.40 & 306.00 & 325.00 \\
3 & S. Plain Cake & Plain Cake & Rectangular & 483.60 & 246.00 & 250.00 \\
4 & M. Plain Cake & Plain Cake & Rectangular & 491.40 & 245.00 & 250.00 \\
5 & Re. Plain Cake & Plain Cake & Rectangular & 491.04 & 242.00 & 250.00 \\
6 & A. Plain Cake & Plain Cake & Rectangular & 476.16 & 238.30 & 250.00 \\
7 & Mu. Plain Cake & Plain Cake & Rectangular & 522.24 & 230.00 & 250.00 \\
8 & N. Plain Cake & Plain Cake & Rectangular & 491.40 & 228.00 & 250.00 \\
9 & O. Plain Cake & Plain Cake & Rectangular & 491.40 & 225.00 & 250.00 \\
10 & R. Fruit Cake & Fruit Cake & Rectangular & 483.84 & 219.00 & 250.00 \\
11 & C. Plain Cake & Plain Cake & Rectangular & 476.16 & 212.00 & 225.00 \\
12 & Y. Plain Cake & Plain Cake & Rectangular & 491.04 & 212.00 & 230.00 \\
13 & L. Plain Cake & Plain Cake & Rectangular & 453.84 & 195.90 & 200.00 \\
\hline
\end{tabular}

Protein content of the cakes varied between $6.5 \%$ to $8.3 \%$ (Table II) indicates that soft wheat flour was used for cake making (Al- Dmoor et al., 2012). Plain cake samples showed lowest proteins content (6.5\%) might be due to no eggs were added during cake making. In addition, baking can result in teins mainly because of the Maillard reaction (Swaminathan et al., 1986).

The ash content was in the range of $0.56 \%-1.29 \%$. Plain cakes exhibited lower ash content whereas fruit cakes show

Table II. Proximate composition of the cakes (g/100g)

\begin{tabular}{|c|c|c|c|c|c|c|c|c|c|}
\hline \multirow[t]{2}{*}{$\begin{array}{l}\text { Sl. } \\
\text { No. }\end{array}$} & \multirow[t]{2}{*}{ Cake } & $\begin{array}{c}\text { Moisture } \\
(\%)\end{array}$ & $\begin{array}{l}\text { Ash } \\
(\%)\end{array}$ & $\begin{array}{c}\text { Fiber } \\
(\%)\end{array}$ & $\begin{array}{l}\text { Fat } \\
(\%)\end{array}$ & $\begin{array}{l}\text { Protein } \\
(\%)\end{array}$ & $\begin{array}{c}\text { Carbohydrate } \\
(\%)\end{array}$ & $\begin{array}{c}\text { Total sugar } \\
(\%)\end{array}$ & $\begin{array}{c}\text { Calorie } \\
\text { (Kcal) }\end{array}$ \\
\hline & & Mean \pm SD & Mean \pm SD & Mean \pm SD & Mean \pm SD & Mean \pm SD & Mean \pm SD & Mean \pm SD & Mean \pm SD \\
\hline 1 & Plain Cake & $81+1$ & 4 & $10 \pm 0.00$ & $25.76 \pm$ & 10 & 09 & $26.38 \pm 0.39$ & \pm 6.51 \\
\hline 2 & R. Fruit Cake & $22.60 \pm 0.20$ & $1.08 \pm 0.01$ & $0.24 \pm 0.01$ & $20.31 \pm 0.54$ & & & $27.11 \pm 0.14$ & \\
\hline 3 & M. Plain Cake & 20.38 & $1.26 \pm$ & $0.01 \pm$ & 25.25 & 8. & 14 & 41 & .00 \\
\hline 4 & Y. Plain Cake & & 3 & 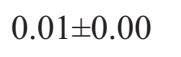 & 2 & & 27 & 28 & 44 \\
\hline 5 & Re. Plain Cake & 2 & 5 & 0 & 17 & & & 91 & .53 \\
\hline 6 & N. Plain Cake & 20.4 & $0.91 \pm$ & 03 & $23.7^{\prime}$ & & & 27.6 & 432 \\
\hline 7 & Ro. Butter Cake & $19.21 \pm .00$ & $0.78 \pm 0.01$ & $0.01 \pm 0.00$ & $21.22 \pm 0.33$ & $6.71 \pm 0.41$ & 52.08 & $29.17 \pm 0.30$ & 426.0 \\
\hline 8 & L-V-N Plain Cake & $22.69 \pm 0.10$ & $57+0.01$ & 00 & 24.1 & 90 & 45. & 25.8 & 428. \\
\hline 9 & A. Plain Cake & $21.53 \pm 0$ & 0 & 01 & 20. & 49 & 06 & 28. & .08 \\
\hline 10 & O. Plain Cake & $21.11 \pm 0.58$ & $0.68 \pm 0.02$ & $0.10 \pm 0.00$ & $23.80 \pm 0.91$ & $8.10 \pm 0.10$ & $46.31 \pm 1.61$ & $26.33 \pm 1.00$ & $432.00 \pm 2.00$ \\
\hline 11 & C. Pl & 44 & & 01 & $26.60=$ & & 43.03 & 23. & \\
\hline 12 & L. Plain Cake & $20.53 \pm 0.16$ & & & & & & & $453.33 \pm 2.52$ \\
\hline 13 & Mu. Plain Cake & $21.90 \pm 0.79$ & $0.69 \pm 0.02$ & $0.01 \pm 0.00$ & $26.13 \pm 0.15$ & $7.90 \pm 0.70$ & $43.38 \pm 1.66$ & $26.10 \pm 0.90$ & $440.33 \pm 2.52$ \\
\hline
\end{tabular}

Means containing same letter do not differ significantly at $5 \%$ level of significance. $(n=3)$ 
slight higher value than plain cakes which might be due to the addition of fruits pulp. However, the values were within the permissible range of BSTI standard. The negligible amount of fiber content (less than $1.0 \%$ ) was found in the analyzed cakes which might be due to the leaching of soluble fibers from the cakes into the oil that remained in the cakes boxes. The carbohydrate content also varied within the ranging between 41.0 to $51.0 \%$. All the thirteen cake samples content almost similar amount. Due to similar amount of fat content calorie content of the products did not vary greatly.

All the eight parameter analyzed including moisture, ash, fiber, fat, protein, carbohydrate, total sugar content and calories of the thirteen retail cake reveal that some of the cake quality is good and some are poor quality.. It is difficult to declare a single cake as best, however, on the basis of the above nutritional parameters cakes showed their superiority over others.

Table III Shows the quality of fats in the cakes. The acid value of most of the cakes ranged from $0.69 \%$ to $4.75 \% \mathrm{mg}$ $\mathrm{KOH} / \mathrm{g}$. The rancidity is usually accompanied by free fatty acid formation. This value is a general indication of the condition and edibility of oils and noticeable when the acidity as iodine values were within the increasing range 62.18 to 120.22. These range of iodine values of extracted oil from cakes indicate that semi drying oils were used for production of cakes. The peroxide values of the products were within the range $20.27-49.4 \mathrm{mEq} / \mathrm{Kg}$. A rancid taste is often just noticeable when the peroxide value is between $10 \mathrm{mEq} / \mathrm{Kg}$ and $20 \mathrm{mEq} / \mathrm{Kg}$ (Cox et al., 1962). Fresh oils normally show no peroxide value. Therefore, oils in the cakes were rancid.

The calorie content of the cakes varied within 429.75 to $530.38 \mathrm{Kcal} / 100$. The main contributor to the calorific value of cakes is carbohydrate because it is the main component of cakes. The gain in energy, especially in oil enrich cakes could be explained by the substantial increase in fat content of that cake.

The classification of cake proteins according to their solubility was studied and distinguished in four different fractions: albumin (water-soluble), globulin (salt-soluble), prolamins (alcohol-soluble) and glutelins (soluble in dilute $\mathrm{NaOH}$ ).

The proportion of cakes proteins fractions is shown in Table IV. Albumin and glutelin were found to be the major protein fraction of cake protein. The denaturation values indicate that the most of the protein in cakes lost the native structure during baking and decreased the solubility. (Swaminathan, 1987).

Table III. Quality indices of fat present in the cakes

\begin{tabular}{llccccc}
\hline $\begin{array}{c}\text { S1. } \\
\text { No. }\end{array}$ & \multicolumn{1}{c}{$\begin{array}{c}\text { Name of the } \\
\text { cake }\end{array}$} & $\begin{array}{c}\text { Total fat } \\
(\mathrm{g} / 100 \mathrm{~g})\end{array}$ & $\begin{array}{c}\text { Acid value } \\
(\mathrm{mgKOH} / 100 \mathrm{~g})\end{array}$ & $\begin{array}{c}\text { Iodine value } \\
(\text { Henus method })\end{array}$ & $\begin{array}{c}\text { Saponification value } \\
(\mathrm{mgKOH} / \mathrm{g})\end{array}$ & $\begin{array}{c}\text { Peroxide value } \\
(\mathrm{mEq} / \mathrm{kg})\end{array}$ \\
\hline 1 & S. Plain Cake & $27.76 \pm 0.20^{\mathrm{bc}}$ & $1.66 \pm 0.55^{\mathrm{c}}$ & $86.29 \pm 1.01^{\mathrm{e}}$ & $209.83 \pm 2.81^{\mathrm{bc}}$ & $35.4 \pm 3.50^{\mathrm{b}}$ \\
2 & R. Fruit Cake & $20.31 \pm 0.54^{\mathrm{f}}$ & $3.03 \pm 0.13^{\mathrm{b}}$ & $119.30 \pm 5.0^{\mathrm{ab}}$ & $231.15 \pm 16.04^{\mathrm{a}}$ & $49.40 \pm 6.9^{\mathrm{a}}$ \\
3 & M. Plain Cake & $25.25 \pm 0.26^{\mathrm{cd}}$ & $0.89 \pm 0.10^{\mathrm{e}}$ & $107.06 \pm 0.06^{\mathrm{d}}$ & $214.39 \pm 4.27^{\mathrm{bc}}$ & $47.20 \pm 7.14^{\mathrm{a}}$ \\
4 & Y. Plain Cake & $24.36 \pm 1.34^{\mathrm{de}}$ & $1.15 \pm 0.05^{\mathrm{cde}}$ & $109.10 \pm 5.10^{\mathrm{d}}$ & $200.80 \pm 11.83^{\mathrm{cd}}$ & $47.46 \pm 5.08^{\mathrm{a}}$ \\
5 & Re. Plain Cake & $17.59 \pm 0.57^{\mathrm{g}}$ & $3.41 \pm 0.00^{\mathrm{b}}$ & $90.23 \pm 0.03^{\mathrm{e}}$ & $199.85 \pm 10.42^{\mathrm{cd}}$ & $45.85 \pm 4.73^{\mathrm{a}}$ \\
6 & N. Plain Cake & $23.77 \pm 0.97^{\mathrm{e}}$ & $4.75 \pm 0.65^{\mathrm{a}}$ & $89.19 \pm 0.0^{\mathrm{e}}$ & $224.42 \pm 9.67^{\mathrm{ab}}$ & $46.40 \pm 1.29^{\mathrm{a}}$ \\
7 & Ro. Butter Cake & $21.22 \pm 0.33^{\mathrm{f}}$ & $4.74 \pm 0.50^{\mathrm{a}}$ & $120.22 \pm 0.0^{\mathrm{a}}$ & $206.20 \pm 7.03^{\mathrm{cd}}$ & $47.10 \pm 6.21^{\mathrm{a}}$ \\
8 & L-V-N Plain Cake & $24.15 \pm 0.72^{\mathrm{de}}$ & $1.56 \pm 0.44^{\mathrm{cd}}$ & $114.80 \pm 3.01^{\mathrm{bc}}$ & $208.20 \pm 15.41^{\mathrm{c}}$ & $48.8 \pm 4.92^{\mathrm{a}}$ \\
9 & A. Plain Cake & $20.79 \pm 0.90^{\mathrm{f}}$ & $0.82 \pm 0.18^{\mathrm{e}}$ & $107.29 \pm 6.83^{\mathrm{d}}$ & $182.82 \pm 3.48^{\mathrm{e}}$ & $21.30 \pm 1.43^{\mathrm{c}}$ \\
10 & O. Plain Cake & $23.80 \pm 0.91^{\mathrm{e}}$ & $0.69 \pm 0.31^{\mathrm{e}}$ & $115.59 \pm 0.41^{\mathrm{ab}}$ & $191.10 \pm 3.58^{\mathrm{de}}$ & $20.27 \pm 2.16^{\mathrm{c}}$ \\
11 & C. Plain Cake & $26.60 \pm 0.59^{\mathrm{ab}}$ & $1.00 \pm 0.0^{\mathrm{de}}$ & $105.21 \pm 0.0^{\mathrm{d}}$ & $181.01 \pm 1.48^{\mathrm{e}}$ & $45.90 \pm 2.94^{\mathrm{a}}$ \\
12 & L. Plain Cake & $27.64 \pm 0.63^{\mathrm{a}}$ & $1.07 \pm 0.07^{\mathrm{cde}}$ & $62.18 \pm 1.14^{\mathrm{f}}$ & $179.62 \pm 9.61^{\mathrm{e}}$ & $47.40 \pm 5.52^{\mathrm{a}}$ \\
13 & Mu. Plain Cake & $26.13 \pm 0.15^{\mathrm{bc}}$ & $0.80 \pm 0.50^{\mathrm{e}}$ & $110.40 \pm 0.0^{\mathrm{cd}}$ & $190.01 \pm 1.78^{\mathrm{de}}$ & $46.10 \pm 3.21^{\mathrm{a}}$ \\
\hline
\end{tabular}

Means containing same letter do not differ significantly at 5\% level of significance. ANOVA test shows that Total Fat, Acid Value, Iodine Value, Saponification value and Peroxide value are significantly different $(\mathrm{p}=0.00)$

oleic acid is about $0.80-1.5 \%$ (Cox et al.,1962). The acid values of oil extracted from seven cakes sample were in the range of $0.69-1.15 \%$ which were beyond the permissible limit and the rest of the cakes oil were rancid. The iodine value is a measure of the degree of unsaturation of oil. The
The mineral contents of the cakes have been shown in Table $\mathrm{V}$. The ash value which represent the presence of inorganicconstituents (minerals) have definite demonstrable functions in the human body and the metabolism (Burton, 1980). Minerals do not act singly in the regulation of body 
Begum, Sarker, Ahmed, Mondal and Anjum

Table IV. Solubility of the protein in the cakes

\begin{tabular}{|c|c|c|c|c|c|c|c|}
\hline \multirow{2}{*}{$\begin{array}{l}\text { Sl. } \\
\text { No. }\end{array}$} & \multirow{2}{*}{$\begin{array}{c}\text { Name of the } \\
\text { cakes }\end{array}$} & \multirow{2}{*}{$\begin{array}{l}\text { Total protein } \\
(\mathrm{g} / 100 \mathrm{~g})\end{array}$} & \multicolumn{4}{|c|}{ Solubility in solvent } & \multirow{2}{*}{$\begin{array}{c}\text { Protein } \\
\text { denatured }\end{array}$} \\
\hline & & & Water & $0.1 \mathrm{M} \mathrm{NaOH}$ & $1 \mathrm{M} \mathrm{NaCI}$ & Alcohol $(10 \%)$ & \\
\hline 1 & S. Plain cake & 6.50 & 3.79 & 0.245 & 0.78 & 1.24 & 96.20 \\
\hline 2 & R. Fruit cake & 7.40 & 0.21 & 0.11 & 0.43 & 2.204 & 98.54 \\
\hline 3 & M. Plain cake & 8.03 & 1.16 & 3.53 & 0.02 & 1.03 & 56.04 \\
\hline 4 & Y. Plain cake & 6.55 & 1.48 & 1.41 & 1.36 & 0.33 & 79.44 \\
\hline 5 & Re. Plain cake & 7.20 & 0.24 & 0.44 & 0.38 & 0.26 & 93.94 \\
\hline 6 & N. Fruit cake & 6.80 & 0.43 & 0.68 & 0.39 & 2.23 & 90.07 \\
\hline 7 & Ro. Butter cake & 6.71 & 1.66 & 0.50 & 0.80 & 0.50 & 92.64 \\
\hline 8 & L-V-N plain cake & 7.10 & 0.26 & 1.48 & 0.36 & 0.39 & 79.15 \\
\hline 9 & A. Plain cake & 7.50 & 0.27 & 1.08 & 0.34 & 0.22 & 85.60 \\
\hline 10 & O. Plain cake & 8.10 & 0.50 & 2.16 & 2.62 & 0.53 & 73.33 \\
\hline 11 & C. Plain cake & 8.06 & 0.17 & 0.81 & 0.78 & 3.62 & 89.91 \\
\hline 12 & L. Plain cake & 8.30 & 0.25 & 3.05 & 0.12 & 0.00 & 63.25 \\
\hline 13 & Mu. Plain cake & 7.90 & 0.50 & 1.18 & 1.00 & 0.10 & 85.06 \\
\hline
\end{tabular}

Table V. Mineral content of the cakes

\begin{tabular}{llccrcc}
\hline Sl.No & Name of the cake & Ash $(\mathrm{g} / 100 \mathrm{~g})$ & $\mathrm{Ca}(\mathrm{mg} / 100 \mathrm{~g})$ & $\mathrm{Ca}(\mathrm{mg} / 100 \mathrm{~g})$ & $\mathrm{Fe}(\mathrm{mg} / 100 \mathrm{~g})$ & $\mathrm{SiO}_{2}(\mathrm{mg} / 100 \mathrm{~g})$ \\
\hline 1 & S. Plain Cake & $0.65 \pm 0.04^{\mathrm{b}}$ & $24.40 \pm 0.03^{\mathrm{j}}$ & $32.04 \pm 0.55^{\mathrm{c}}$ & $1.80 \pm 0.03^{\mathrm{h}}$ & $0.29 \pm 0.02^{\mathrm{a}}$ \\
2 & R. Fruit Cake & $1.08 \pm 0.01^{\mathrm{ab}}$ & $44.14 \pm 0.14^{\mathrm{h}}$ & $69.70 \pm 0.30^{\mathrm{a}}$ & $8.18 \pm 0.02^{\mathrm{a}}$ & $0.20 \pm 0.05^{\mathrm{bc}}$ \\
3 & M. Plain Cake & $1.26 \pm 0.06^{\mathrm{ad}}$ & $114.63 \pm 0.38^{\mathrm{c}}$ & $40.01 \pm 0.01^{\mathrm{b}}$ & $6.32 \pm 0.04^{\mathrm{b}}$ & $0.08 \pm 0.03^{\mathrm{fg}}$ \\
4 & Y. Plain Cake & $1.07 \pm 0.03^{\mathrm{ab}}$ & $131.55 \pm 0.45^{\mathrm{b}}$ & $39.08 \pm 4.92^{\mathrm{b}}$ & $5.60 \pm 0.0^{\mathrm{c}}$ & $0.19 \pm 0.02^{\mathrm{bcd}}$ \\
5 & Re. Plain Cake & $0.65 \pm 0.55^{\mathrm{b}}$ & $83.18 \pm 0.07^{\mathrm{e}}$ & $38.55 \pm 2.45^{\mathrm{b}}$ & $2.01 \pm 0.15^{\mathrm{g}}$ & $0.09 \pm 0.03^{\mathrm{f}}$ \\
6 & N. Plain Cake & $0.91 \pm 0.49^{\mathrm{ab}}$ & $132.62 \pm 0.50^{\mathrm{b}}$ & $41.05 \pm 0.95^{\mathrm{b}}$ & $2.31 \pm 0.0^{\mathrm{e}}$ & $0.11 \pm 0.02^{\text {def }}$ \\
7 & Ro. Butter Cake & $0.78 \pm 0.01^{\mathrm{ab}}$ & $149.15 \pm 5.05^{\mathrm{a}}$ & $42.11 \pm 0.0^{\mathrm{b}}$ & $0.96 \pm 0.07^{1}$ & $0.16 \pm 0.04 \mathrm{~cd}^{\text {cdef }}$ \\
8 & L-V-N Plain Cake & $0.57 \pm 0.01^{\mathrm{b}}$ & $55.33 \pm 0.0^{\mathrm{f}}$ & $38.80 \pm 1.50^{\mathrm{b}}$ & $1.59 \pm 0.11^{\mathrm{i}}$ & $0.10 \pm 0.01^{\mathrm{ef}}$ \\
9 & A. Plain Cake & $0.73 \pm 0.66^{\mathrm{b}}$ & $41.81 \pm 1.39^{\mathrm{h}}$ & $37.89 \pm 4.45^{\mathrm{b}}$ & $2.63 \pm 0.03^{\mathrm{d}}$ & $0.27 \pm 0.07^{\mathrm{ab}}$ \\
10 & O. Plain Cake & $0.68 \pm 0.02^{\mathrm{b}}$ & $48.11 \pm 0.10^{\mathrm{g}}$ & $39.12 \pm 4.88^{\mathrm{b}}$ & $2.1 \pm 0.14^{\mathrm{f}}$ & $0.19 \pm 0.07^{\mathrm{bcd}}$ \\
11 & C. Plain Cake & $0.66 \pm 0.01^{\mathrm{b}}$ & $38.00 \pm 0.01^{\mathrm{i}}$ & $40.15 \pm 0.05^{\mathrm{b}}$ & $1.01 \pm 0.03^{\mathrm{k}}$ & $0.18 \pm 0.07^{\mathrm{cde}}$ \\
12 & L. Plain Cake & $0.70 \pm 0.02^{\mathrm{b}}$ & $88.81 \pm 0.51^{\mathrm{d}}$ & $41.91 \pm 0.49^{\mathrm{b}}$ & $1.16 \pm 0.14^{\mathrm{j}}$ & $0.19 \pm 0.06^{\mathrm{bcd}}$ \\
13 & Mu. Plain Cake & $0.69 \pm 0.02^{\mathrm{b}}$ & $48.01 \pm 0.01^{\mathrm{g}}$ & $40.77 \pm 0.13^{\mathrm{b}}$ & $1.98 \pm 0.13^{\mathrm{g}}$ & $0.01 \pm 0.001^{\mathrm{g}}$ \\
\hline
\end{tabular}

Means containing same letter do not differ significantly at $5 \%$ level of significance.

ANOVA test shows that Ash content in different cakes do not vary significantly $(\mathrm{p}=0.12)$. However, percentage of Na, Ca, $\mathrm{Fe}$ and $\mathrm{SiO}_{2}$ are significantly different $(\mathrm{p}=0.00)$

processes but work with the help of other minerals and organic compounds (Gupta et al., 2000). Acid insoluble ash ( silica) in five cakes sample $(0.01$ to $0.11 \mathrm{mg} / 100 \mathrm{~g})$ complies with the BSTI approved specification. On the other hand, the remaining eight cakes sample contains 0.16 to 0.31 $\mathrm{mg} / 100 \mathrm{~g}$ of acid insoluble ash, which is out of BSTI standard. The results of calcium and sodium analyses appear reasonable in view of the calcium and sodium content listed for grain screenings and wheat screenings by Edmund (2008). The iron content of the cakes was within the acceptable range comparing to the other processed foods (Kirk, 1991).

\section{Conclusion}

The results of this investigation indicated that only 2 cake samples $(15.38 \%)$ among 13 was found to comply with all the parameters checked with BSS and majority of the retail cake samples does not comply with the BSS specifications. Therefore regulatory authorities should pay attention in this matter to ensure product quality. Moreover the nutrient content of the cakes in many cases were encouraging however the information on the nutrients content of various cakes is virtually important for the nutritionist, dietitians, food plan- 
ners, consumers and for others working in this field. Above all the information is very much essential for the consumers to make a good bargain for food economy.

\section{Acknowledgement}

The authors are grateful to Mr. Musa Chowdhury, PSO, Medicinal Chemistry Research Section, Chittagong Laboratory, BCSIR, for determining minerals content of the samples by Flame Photometer.

\section{References}

Ahmed S, Rahman S, Ahmad R, Kabirullah M, Hossain MM, Kazi MAI and Housain MM (2000), Bangladesh J. Sci. Ind. Res., 35(1-4): 44-50.

Al-Dmoor H (2012), Production of Cakes from Hard Wheat Flour. Submit for publishing in quality Assurance and Safety of Crops \& Foods.

ANON (1970), Oxygen Bomb Calorimetry and Combustion Methods. Manual No.130. Parr Instrument Co.

AOAC (Association of Official Analytical Chemists) 91980), Official Methods of Analysis. 9th Ed. Washington.

AOAC (1975), Official Methods of Analysis of Association of Official Analytical Chemists. $12^{\text {th }}$ Ed. AOAC Inc. Washington D.C.USA.

AACC (American Association of Cereal Chemist) (2000), Approved methods of the Methods of American Association of Cereal Chemists. $11^{\text {th }}$ Ed. St. Paul MN.

Anon http://www. Aaccnet.org/ approved methods/ toc.aspx

Anuradha D, Desai Kulkarni SS, Sahoo AK, RanveerRC and Dandge PB (2010), Advance Journal of Food Science and Technology 2(1): 67-71.

BSTI. (2006), Bangladesh Standard Specification for cake, BDS 1574: 2006.

Burton TB (1980), Human Nutrition: Formerly The Heinz Handbook of Nutrition. $3^{\text {rd }}$ Ed. New York. Tata McGraw-Hill Publishing Company Ltd. 127.

Cauvain SP and Young LS (2006), Baked Products: Science, Technology and Practice. Wiley-Blackwell. Oxford.

Cox HE and David P (1962), The Chemical Analysis of Foods Chemical Publishing Co. Inc., New York, pp 420-421.

Dotsey P (2009), The use of cocoyam, cassava and wheat flour composite in the production of rock cake, HND
Dissertation, Cape Coast Polytechnic, Cape Coast, Ghana, 1: 7-40.

Edmund JT and Perry WK (2008), Soft Wheat Quality. In: Food Engineering Aspects of Baking Sweet Goods. Servet G. S. and Serpil S. CRC Press.1-30.

Ghysuddin S, Carter CM and Mattil CF (1970), J. Food Sci., 35: 453.

Gupta Kusum, Gupta, LC, Gupta A (20000, Food and Nutrition: Facts and Figures. $5^{\text {th }}$ Ed. Delhi. Jaypee Brothers Medical Publishers Ltd. 46.

ICMR (Indian Council of Medical Research). (1974), Nutritive Value of Indian foods.

Kirk SR and Sawyer R (1991), Pearson's Composition and Analysis of Foods. $9^{\text {th }}$ Ed. England: Addison Wesley Longman Ltd. 686

Malik SK and Salam SA (1976), Pak. J. Sci. Res., 28: 90-94.

Manay NS. and Shadaksharaswamy M (1987), Foods: Facts and Principles, Wiley Eastern Limited, New-Delhi. 432-435.

Kabirullah M, Ahmad R, Khan SA, Saha BK, Rahman AKMM, Kazi MAI and Hossain MM (1997), Bangladesh J. Sci. Ind.Res., 32(4): 615-629.

Rita E, Sanful, Adiza Sadik and Sophia Darko (2010), Pakistan Journal of Nutrition, 9(8): 794-796.

Rahman KMM (1999), Bangladesh J. Sci. Ind. Res., 34 (34):397-403.

Swaminathan M (1986), Handbook of Food and Nutrition. 5th Edition. Bangalore. Bangalore Publishing Co. Ltd.131 - 133.

Swaminathan M (1987), Food Science, Chemistry and Experimental Foods. Bangalore: Bangalore Printing and Publishing Co. Ltd. 38.

Tull A (2000), Food and Nutrition. $3^{\text {rd }}$ Ed. University Press: $32-40$.

Vogel AI (1958), A Text Book of Quantitative Inorganic Analysis including Elementary Instrument analysis, London. Longmans. Green and Co.743.

Vogel AI (1968), A Text Book of Quantitative Inorganic Analysis including Elementary Instrument analysis, The English Language book Society \& Longmans. 655-658.

Wills RBH, Balmer N and Greenfield H (1980), Food Tech. Australia, 32(4): 198-202.

Received: 27 November 2013; Revised: 19 October 2015; Accepted : 31 January 2016. 